\title{
HUMIDIFICATION OF ANAESTHETIC GASES
}

\author{
B. KAY, F.F.A.R.C.S. AND T. AlLEN
}

THE NECESSITY To humidify adequately anaesthetic gases being administered to infants has long been recognised, ${ }^{1}$ particularly during long operations. Unfortunately the commonly used Jackson Rees type T-piece system, as made up for instance from the MIE infant apparatus, supplies dry gases and does not retain much exhaled water vapour.

Several extensive investigations into the efficacy of various types of humidifier have been carried out, such as that by Hayes and Robinson. ${ }^{2}$ However, the present tests were made to compare the adequacy of some common nebulizers in humidifying the dry anaesthetic gases from a Boyle anaesthetic machine and supplying them into the tube leading to the T-piece. Nebulizers were chosen because it was expected that the mist entering the endotracheal tube would allow some evaporation as the gases warm to body temperature, maintaining a high relative humidity. Also the deposition of some larger droplets on the mucous membranes would further counteract the effect of atropine on the bronchial mucus. The nebulizers tested will conveniently stand on the Boyle table top.

\section{METHOD}

Three cold nebulizers were tested, namely the Winliz, the Bird $500 \mathrm{ml}$, and the Puritan 126. The Puritan was tested also as a heated nebulizer. The De Vilbiss 900 , an ultrasonic nebulizer, was also investigated, and the Bennett Cascade was included as a representative heated humidifier.

The various nebulizers were adapted to receive gas from the anaesthetic machine, 5 litres of oxygen $/ \mathrm{min}$ being delivered into the usual high-pressure gas inlet. The gas was similarly led into the Cascade humidifier, but into the nebulizing chamber of the De Vilbiss machine (used on maximal setting for humidity) instead of the air inlet. The humidified gas was then delivered to the T-piece by conductive rubber tubing of 9-mm diameter and 4-mm bore, 1 metre long. The whole system was rendered gas-tight to prevent loss or dilution of gas flow. For this same reason the Puritan nebulizer was tested only on the 100 per cent setting, thus avoiding air entrainment. Ambient temperature was maintained at $22^{\circ} \mathrm{C}$.

The T-piece was connected by Knight's connections to a size $3.5-\mathrm{mm}$ cuffed endotracheal tube, which led into an Ellab* special psychrometer functioning as a mock "trachea". The endotracheal tube cuff was blown up to ensure that all the gas flowed through the psychrometer. (Figure 1) The wet and dry thermister readings were recorded on an Ellab TE3 electric thermometer. In order that the full flow passed through the psychrometer no expiratory tube was attached to the T-piece and the orfice was occluded.

${ }^{*}$ Electrolaboratoriet Ellab A/s Copenhagen. 


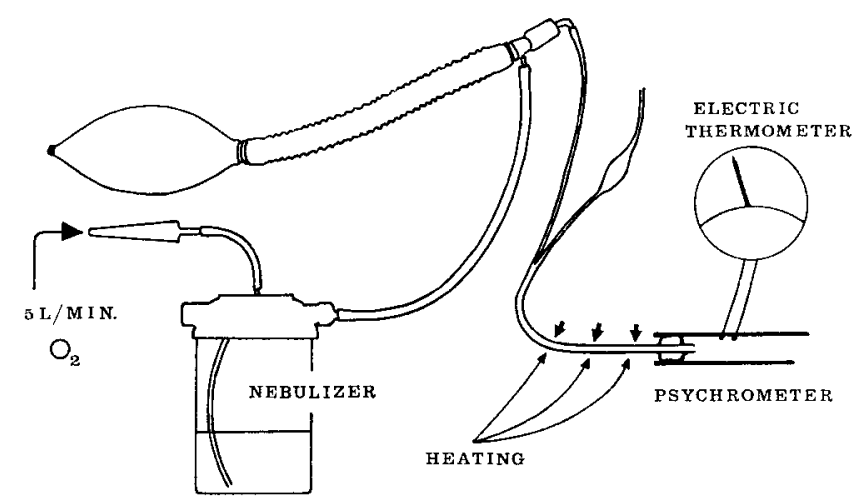

FIGURE 1. Diagramatic representation of equipment as assembled.

The efficiency of the nebulizers was demonstrated first at room temperature, using the wet and dry temperature readings to determine the water vapour pressure from which the relative humidity was calculated.

In order to simulate the conditions in the infant's trachea the endotracheal tube was then warmed so that the dry (high) temperature reading was $37^{\circ} \mathrm{C}$, and the resulting relative humidities similarly calculated. In both series the unhumidified oxygen was also tested. The heating of the endotracheal tube was effected by a small variable controlled-temperature waterbath.

\section{Results}

Table I shows that all machines were completely effective at room temperature.

Table II shows the results when the gases entering the psychrometer were at body temperature. The Puritan nebulizer was heated by the Puritan T.r. heater adjusted as nearly as possible to give gas leaving the endotracheal tube at $37^{\circ} \mathrm{C}$ without further heating. The Cascade humidifier, however, was unable to achieve this even on maximum setting (9), the further heating required reducing the relative humidity obtained.

As expected, the ultrasonic nebulizer was completely effective, even after heating the gases to body temperature, and the cheaper cold nebulizers were less so.

It must be emphasized that none of the nebulizers used was designed for incorporation into an anaesthetic circuit, and indeed one would expect very poor results with the three cold nebulizers which should be driven by a high-pressure gas source, providing high flows.

Moreover, no one has concluded what is the optimal amount of humidity to be added to anaesthetic gases, or the total effects of an excess amount.

However, despite their inherent disadvantages, each nebulizer succeeded in adding a significant, and probably desirable and effective amount of water vapour to the gas in the endotracheal tube at body temperature. The main problems are practical ones.

The Winliz nebulizer is fairly large, was difficult to make gas-tight, and required 
TABLE I

\begin{tabular}{lcccc}
\hline \hline & $\begin{array}{c}\text { Ory } \\
\text { (high) } \\
\text { temp } \\
\text { (') }\end{array}$ & $\begin{array}{c}\text { Wet } \\
\text { (low) } \\
\text { temp } \\
\left({ }^{\circ} \mathrm{C}\right)\end{array}$ & $\begin{array}{c}\text { Vapour } \\
\text { pressure } \\
\text { (mm Hg) }\end{array}$ & $\begin{array}{c}\text { Relative } \\
\text { humidity } \\
\text { (percent) }\end{array}$ \\
\hline None & 22 & 7 & 0 & 0 \\
Winliz & 22 & 22 & 20 & 100 \\
Bird & 22 & 22 & 20 & 100 \\
Puritan & 22 & 22 & 20 & 100 \\
Cascade & 22 & 22 & 20 & 100 \\
De Vilbiss & 22 & 22 & 20 & 100 \\
\hline
\end{tabular}

TABLE II

\begin{tabular}{|c|c|c|c|c|}
\hline Hunidifier & $\begin{array}{c}\text { Dry } \\
\text { (high) } \\
\text { teml } \\
\text { (oc) }\end{array}$ & $\begin{array}{l}\text { Wet } \\
\text { (low) } \\
\text { temp } \\
\left({ }^{\circ} \mathrm{c}\right)\end{array}$ & $\begin{array}{l}\text { Vapour } \\
\text { pressure } \\
\text { (mm Hg) }\end{array}$ & $\begin{array}{l}\text { Relative } \\
\text { humidity } \\
\text { (percent) }\end{array}$ \\
\hline None & $: 37$ & $1 \pi$ & 0 & 0 \\
\hline Winliz & 37 & $2 !$ & 26 & 56 \\
\hline Bird & 37 & $3 \%$ & 36 & 76 \\
\hline Puritan (heated) & 37 & 36 & 45 & 95 \\
\hline Puritan (unheated) & 37 & 29 & 26 & 56 \\
\hline Cascado & 37 & 32 & 33 & 71 \\
\hline De Vilbiat & $\because 3$ & $: 37$ & $4 \bar{i}$ & 100 \\
\hline
\end{tabular}

the manufacture of special adaptors to enable its inclusion in the anaesthetic circuit.

The Puritan nebulizer is compact and easily inserted into the anaesthetic circuit. However, the resistance of the nebulizer is very high and a high pressure must be provided by the reducing valves of the anaesthetic machine in order to drive 5 litres/min of gas through it. In these conditions we found it necessary to wire together all connections between the machine and the nebulizer to prevent disconnection.

The Bird nebulizer is also compact, is inserted into the circuit very conveniently, and is of sufficiently low resistance to function easily at a flow of 5 litres $/ \mathrm{min}$. The nebulizer we used also provided an effective degree of relative humidity, and as a result of our investigations this nebulizer is now used routinely on all our infants requiring endotracheal anaesthesia, except for very short operations.

The heated Puritan nebulizer and Cascade humidifier were effective, but not easily inserted in circuit. Both suffer from the major disadvantage of heated humidifiers, in the fact that in order to allow high humidity by the time the gas reaches the endotracheal tube, the gas must be heated well above body temperature at source. Thus for safety it is necessary to continuously monitor the temperature of the gas entering the endotracheal tube, which is an inconvenient and time-consuming procedure. Further inconveniences are the amount of water that condenses out of the cooling anaesthetic gases as they pass through the tubing, and the necessity for an electricity supply to the humidifier.

Finally, the De Vilbiss ultrasonic nebulizer was completely effective. It is however, expensive, requires a separate stand and is dependent upon electricity. It 
must also be regulated so that a gross excess of mist is not supplied, causing undue precipitation of water droplets and increased resistance in the circuit and in the infant's airways and lungs. ${ }^{3}$

\section{SUMMARY}

In an effort to find a convenient method of humidifying anaesthetic gases being administered to infants by endotracheal tube, a number of commonly available nebulizers were investigated. Their effectiveness was determined in a simulated tracheal situation. The problems of their practical application are discussed.

\section{RÉSUMÉ}

Dans le but de trouver une méthode appropriée d'humidifier les gaz anesthésiques administrés par un tube endotrachéal, nous avons fait des études sur les nébulizateurs d'usage courant. Nous avons déterminé leur efficacité par un montage simulant une intubation endotrachéale. Nous discutons les problèmes de leur application clinique.

En dépit de leurs désavantages inhérents, tous les nébulizateurs ont réussi à ajouter aux gaz dans le tube endotrachéal, à la température du corps, une quantité de vapeur d'eau considérable, probablement désirable et efficace. Les principaux problèmes sont d'ordre pratique.

Le nébulizateur Winliz est plutôt volumineux, il a été difficile de le rendre étanche : le manufacturier a dû fabriquer des adapteurs spéciaux pour que nous puissions l'inclure dans le circuit anesthésique.

Le nébulizateur Puritan est de petit volume et peut s'insérer facilement dans le circuit anesthésique. Toutefois, la résistance du nébulizateur est très élevée et les valves réductrices de la machine à anesthésie doivent fournir une pression élevée pour réussir à y faire passer un débit de $5 \mathrm{l} /$ minute de gaz. A cause de cet état de chose, nous avons dû ficeler tous les joints entre la machine et le nébulizateur pour éviter que les joints ne se détachent.

Le nébulizateur Bird est aussi de petit volume; il s'insère dans le circuit très facilement et la résistance qu'il crée est assez basse qu'il peut fonctionner facilement à un débit de $5 \mathrm{l} /$ minute. Le nébulizateur que nous avons employé a fourni un degré assez élevé d'humidité relative que, à la suite de nos études, nous l'employons de routine chez tous les enfants qui doivent avoir une anesthésie endotrachéale, à l'exception des opérations courtes.

Le nébulizateur chauffé Puritan et l'humidificateur Cascade ont été efficaces mais difficiles à insérer dans le circuit. Les deux appareils ont le désavantage important d'être des humidificateurs chauffés; de fait, de façon à obtenir un taux élevé d'humidité au moment où les gaz traversent le tube endotrachéal il faut les chauffer à une température de beaucoup supérieure à celle du corps et cela, à la source. Ainsi, pour raison de sécurité, il faut surveiller continuellement la température des gaz qui entrent dans le tube endotrachéal, ce qui est malcommode et fait perdre du temps. D'autres ennuis sont occasionnés d'une part, par la quantité d'eau qui se condense sur le refroidisseur des gaz anesthésiques au passage des gaz, et d'autre part, par la nécessité d'un apport d'électricité pour l'humidificateur. 
Enfin, le nébulizateur ultrasonique De Vilbiss a été tout à fait efficace. Toutefois, il coûte cher, requiert un support séparé et de l'électricité pour fonctionner. Il nécessite un contrôle de façon à ce qu'un excès important d'humidité ne soit produit et n'entraine une précipitation de gouttelettes d'eau, ce qui augmenterait la résistance dans le circuit et dans les poumons de l'enfant.

\section{REFERENCES}

1. Editorial. Brit. 1. Anaesth., 42: 271 (1970).

2. Hayes, B. \& Robinson, J. S. An Assessment of Methods of Humidification of Inspired Gas. Brit. J. Anaesth., 42: 94 ( 1970$)$.

3. Tounge, J. K.; Alvaran, S. B.; Shakoar, M. A.; Graff, T. D. \& Benson, D. W. Alveolar Surface Activity Following Mechanical Endotracheal Ventilation with High-Density Water Mist. Anesth. \& Analg., 49: 851 (1970). 